\title{
Incidence of Potyviruses on Two Wild Yams Species, Potential Varietal Improvement Plant Genetic Resources, Involved in Farmers' Domestication Process in Togo
}

\author{
Kwasi Dzola Ayisah $^{1 *}$, Gbenonchi Mawussi ${ }^{2}$ and Larounga Tchaniley ${ }^{1}$ \\ ${ }^{1}$ Department of Plant Breeding and Crop Science, ${ }^{2}$ Laboratory of Research on \\ Agroresources and Environmental Health, Ecole Supérieure d'Agronomie, \\ Université de Lomé, B. P. 1515, Lomé, Togo
}

*Corresponding author

\section{A B S T R A C T}

\section{Keywords}

Potyvirus, Yam mosaic virus, Yam mild mosaic virus,

Dioscorea

abyssinica,

Dioscorea

praehensilis,

Incidence rate

Article Info

\section{Accepted:}

xx September 2020

Available Online:

xx October 2020

\begin{abstract}
Yams grown in Togo are severely infected by Yam mosaic virus (YMV) and Yam mild mosaic virus (YMMV), genus Potyvirus. The present work aims to study the susceptibility, to potyviruses, of wild species Dioscorea praehensilis and Dioscorea abyssinica, which can be exploited for the search for resistant genotypes. Thus, 107 leaf samples of D. abyssinica and 72 of D. praehensilis collected in the Maritime, Plateaux, Centrale and Kara regions were analyzed by ACP-ELISA to detect Potyviruses and then by RT-PCR to detect YMV and YMMV, using primers YMV1 \& YMV2 and YMV-CP2F \& YMV-UTR-1R, respectively. Following ACP-ELISA analyzes, in Plateaux region, $20.69 \%$ of samples of $D$. abyssinica and $2.78 \%$ of D. praehensilis were positive for potyviruses. In Kara and Central regions, $33.33 \%$ and $1.41 \%$ respectively of D. abyssinica samples were positive. RT-PCR analyzes did not reveal any positive samples for YMMV. However, a leaf sample of $D$. abyssinica in domestication and another of $D$. praehensilis taken from near a yam plot were positive for YMV. The two yam species, less sensitive to Potyviruses, YMV, YMMV, could be potential sources of resistance.
\end{abstract}

\section{Introduction}

Cultivated yams (Dioscorea spp.), especially yams of the complex Dioscorea cayenensisrotoundata, represent the third food crop in Togo after maize and cassava, with an estimated annual production of 858,783 tones (FAOSTAT, 2020). However, yam cultivation in the country is hampered by viral diseases (Adjata, 1991), in particular those caused by Potyviruses, including Yam mosaic virus
(YMV) and Yam mild mosaic virus (YMMV) (Ayisah et al., 2011, Ayisah, 2012). These Potyviruses have in fact been considered in West Africa to be the most prevalent viruses and the most economically damaging to yam plants (Hughes et al., 1998; Attiri et al., 2003).

To effectively control yam virus diseases, the appropriate solution will be to create resistant varieties of yams that can be exploited in a 
sustainable manner using wild yams, more specifically, the species Dioscorea praehensilis and Dioscorea abyssinica, as basic plant genetic resources. Indeed, both species of yams are involved in the domestication process in rural communities in Togo and elsewhere in West Africa (Mignouna and Dansi, 2003). Moreover, according to Hamon (1987), yams of the complex D.cayenensis-rotoundata, in particular the species $D$. rotundata, come from the wild yam species $D$. praehensilis and $D$. abyssinica. The susceptibility of these wild yams to viral diseases in their natural habitats has not yet been formally demonstrated. Nevertheless, studies have demonstrated spontaneous hybridizations between the two wild species $D$. abyssinica and $D$. praehensilis and the cultivated species D. cayenensis-rotundata (Scarcelli et al., 2006). Some of these wild interspecific hybrids can also be susceptible to viruses such as cultivated yams. Thus, for reliable varietal selection, it is essential to take an inventory of the Potyviruses which infect these wild yams in their habitats and to know the genetic links between the said Potyviruses and those which infect yams cultivated in the country.

The objective of the present work is to collect data on the virological environment of the wild yam species D.praehensilis and D.abyssinica still in domestication in the country. Specifically, it was a question of identifying the Potyviruses in general, on wild yams $D$. praehensilis and $D$. abyssinica in different environments and to evaluate, in particular, their sensitivities to YMV and YMMV.

\section{Materials and Methods}

\section{Study areas}

The studies were carried out in four economic regions of Togo which are also major yam production areas of the country. These are the Maritime (6 ${ }^{\circ} 30^{\prime} 0$ "N, $\left.1^{\circ} 19^{\prime} 60^{\prime \prime} \mathrm{E}\right)$, Plateaux $\left(7^{\circ} 30^{\prime} 0\right.$ "N, $\left.1^{\circ} 10^{\prime} 0 " \mathrm{E}\right)$, Central ( ${ }^{\circ} 15^{\prime} 0$ "N, $\left.1^{\circ} 0^{\prime} 0^{\prime \prime} \mathrm{E}\right)$ and Kara ( $\left.9^{\circ} 33^{\prime} \mathrm{N}, 1^{\circ} 11^{\prime} \mathrm{E}\right)$ regions. The Maritime and Plateaux regions have a subequatorial climate with two rainy seasons including a long rainy season (midMarch to late July) and a small rainy season (early September to mid-November). Annual rainfall varies from $800 \mathrm{~mm}$ to $1600 \mathrm{~mm}$. The Central region has a Sudano-Guinean climate with only one rainy season (end-April to endOctober). The average annual precipitation is $1300 \mathrm{~mm}$. The Kara region has a Sudanesetype climate with a single rainy season (midMay to end-October) and an average annual rainfall of between 900-1000 mm (ITRA, 2009).

\section{Plant material}

The work was carried out on leaves of wild yam species $D$. praehensilis and $D$. abyssinica. Some of the leaf samples were taken from farmers' fields on yam plants in domestication. In total, 179 leaf samples were collected for the detection of Potyviruses in laboratory (Table 1).

\section{Antibodies and primers used}

Universal anti-Potyvirus monoclonal antibodies (Agdia Inc.) were used to identify Potyviruses in yam leaves. In addition, two pairs of primers, YMV1 \& YMV2 and YMVCP-2F \& YMV-UTR-1R, were used to detect YMV and YMMV respectively in leaf samples previously tested positive for Potyviruses (Table 2).

\section{Wild yam leaves collection}

Leaves of wild yams showing apparent symptoms of virus disease were collected from four of the five major yam production areas in Togo. The collection of yam leaf 
samples covered 16 Districts, including 1 in Maritime region, 7 in Plateaux region, 5 in Central region and 3 in Kara region (Table 3). The yam leaf samples were taken in different environments including forests far from any crop, forests located near cultivated yam plots, but also in farmers' fields on wild yam plants in domestication. The leaf samples were stored on the fields in a cooler containing ice and then at $-20^{\circ} \mathrm{C}$ in the Laboratory of Virology and Plant Biotechnologies.

\section{Poty viruses immunological identification}

The leaf samples collected were analyzed by ACP-ELISA test (Antibody coating plat Enzymelinked immunosorbent assay) according to the protocol provided by Agdia Inc as follows: fragments of $0.25 \mathrm{~g}$ yam leaves were ground in $5 \mathrm{ml}$ of $0.05 \mathrm{M}$ carbonate buffer ( $\mathrm{pH} 9.6)$ supplemented with $2 \%$ PVP, then $100 \mu \mathrm{l}$ of extract from each leaf sample were loaded in the wells of the microtiter plates (plates Nunc). The plates were then incubated at room temperature for 1 hour and after three rinses with PBST1X containing Tween $20(0.05 \%)$, they were filled with the first anti-potyvirus monoclonal antibody diluted to $1 / 200$. After incubation overnight at $+4{ }^{\circ} \mathrm{C}$ and after three successive rinses, the plates were filled with the "goat anti-mouse" conjugate antibody (dilution: 1/200) and then incubated for 1 hour at room temperature. At the end of the incubation followed by four washes, $200 \mu 1$ of substrate extemporaneously prepared (1 $\mathrm{mg}$ of $\mathrm{p}$ paranitrophenyl phosphate for $1 \mathrm{ml}$ of buffer) were, dispensed into each well and then the plates were incubated in total darkness for 30 minutes at room temperature. The reactions were read on a spectrophotometer Multiskanat $405 \mathrm{~nm}$. On reading, the wells having an O.D. (optical density) greater than or equal to the double of the O.D. of the healthy control, were considered as positive.

\section{Molecular detection of YMV and YMMV}

Yam leaf samples positive at ACP-ELISA test, were analyzed by RT-PCR for the detection of YMV and YMMV. These two viruses were detected in duplex in the leaf samples according to the protocol which is as follows: PCR tubes $(0.2 \mathrm{ml}$, Starlab) were filled with extracts $(25 \mu \mathrm{l} / \mathrm{tube})$ obtained by grinding $0.5 \mathrm{mg}$ of yam leaf in $5 \mathrm{ml}$ of carbonate buffer (pH9.6) and after centrifugation at $+4{ }^{\circ} \mathrm{C}$ and at 6000trs / min for $5 \mathrm{mn}$. The tubes, after incubation overnight at $+4^{\circ} \mathrm{C}$, were rinsed twice with sterilized PBS 1X containing Tween $20(0.05 \%)$ and once with sterile water-DEPC. Leaves taken from healthy yam plants in the greenhouse served as negative controls. The RT-PCR was carried out by adding to the contents of each PCR tube, $25 \mu l$ of RT-PCR reaction mixture (QiAgen one step RT-PCR kit) containing the detection primers for YMV (YMV1 \& YMV2, $10 \mu \mathrm{M}$ ) and YMMV (YMVCP2F \& YMVUTR1R, $1 \mu \mathrm{M}$ ).

The RT-PCR reactions were carried out in thermocycler Biometra under the following conditions: one retrotranscription cycle $\left(50^{\circ}\right.$ $\mathrm{C}$ for $30 \mathrm{~min}$ then $95^{\circ} \mathrm{C}$ for $15 \mathrm{~min}$ ), $35 \mathrm{PCR}$ cycles (denaturation: $94{ }^{\circ} \mathrm{C}$ for $1 \mathrm{~min}$, hybridization: $55 \circ \mathrm{C}$ for 1 minute; elongation: $72{ }^{\circ} \mathrm{C}$ for 1 minute) and 10 minutes of elongation at $72^{\circ} \mathrm{C}$ to complete the cycles. At the end of the reactions, $12 \mu \mathrm{l}$ of PCR product (cDNA) from each tube mixed with $2 \mu 1$ of $6 x$ loading buffer $(2 \mathrm{mM}$ Tris- $\mathrm{HCl}$ $\mathrm{pH} 8,10 \mathrm{mM}$ EDTA, 5\% sucrose, $0.01 \%$ bromophenol blue), were loaded on agarose gel $(1.5 \%)$ prepared in $0.5 \mathrm{x}$ TBE buffer $(100$ $\mathrm{mM}$ Tris Borate $\mathrm{pH} 8.3,2 \mathrm{mM}$ EDTA). A standard size marker of $1 \mathrm{~kb}$ was also loaded on the gel. The electrophoresis was carried out in $0.5 \mathrm{x}$ TBE buffer for 35 minutes at a voltage of $100 \mathrm{~V}$. The agarose gel was coloured at the end of the electrophoresis in Ethidium Bromide for 15 min and washed for 
5 min. The electrophoretic bands were visualized on a UV trans-illuminator.

\section{Results and Discussion}

\section{Incidence of Potyviruses}

The results of the ACP-ELISA, reported in Tables 4 and 5, indicated that, of the 179 leaf samples of D. praehensilis and D. abysinica analyzed, only 12 were positive, i.e. an estimated incidence rate of Potyviruses at $6.70 \%$ for both species of yam. However, it should be noted that, depending on the yam species and the regions where the leaf samples were collected, the results obtained were variable. In $D$. abyssinica species, of the 107 leaf samples analyzed, 10 were positive, i.e. an estimated incidence rate of Potyviruses. at $9.35 \%$. Among these positive samples, 3 were collected from yam plants in domestication, 2 were taken from a forest near a plot of cultivated yams while 5 were collected from forests far from any cultivation. In $D$. praehensilis species, only 2 of the 72 samples analyzed were positive, for an estimated incidence rate of Potyvirus of $2.78 \%$. One of the positive samples of this yam species was collected from a yam plant in domestication while the second came from a forest close to a cultivated yam plot.

At the level of the Districts, as shown in Table 4, in the Maritime and Plateaux regions, at least one leaf sample of $D$. abysinica among those collected in the Districts of the Gulf, Ogou, Anié and Est-Mono, was positive for Potyviruses. On the other hand, in the Central region, among the five districts surveyed, only 1 leaf sample of $D$. abyssinica collected in the District of Blitta was positive. In the Kara region, of the three districts surveyed, 1 sample from Bassar District and 1 from the Kéran District were positive. In $D$. praehensilis, among the samples taken in seven Districts of Plateaux region, only 2 samples from the District of Agou were positive. No samples of $D$. praehensilis collected in Blitta District, in Central region, were positive.

The results concerning the regions of collection of the yam leaf samples analyzed, showed that in the Plateaux region, of the 29 samples of $D$. abyssinica analyzed, only 6 were positive, i.e. an incidence rate of potyviruses estimated at $20.69 \%$ while in $D$. praehensilis, of the 63 leaf samples analyzed, only 2 were positive, ie an estimated potyvirus incidence rate of $2.78 \%$. On the other hand, in the three other regions, only the samples of $D$. abyssinica were positive, including 1 sample from the Maritime region (incidence rate $100 \%$ ), 2 samples from Kara region on a total of6samples analyzed (i.e. $33.33 \%$ of the viruses incidence rate) and 1 sample from the Central region, of the 71 samples analyzed, i.e. $1.41 \%$ Potyvirus incidence rate.

As shown by the results in Table 5, all the 3 leaf samples taken from plants of $D$. abyssinica in domestication, were positive. On the other hand, in D. praehensilis, only 1 of the 11 leaf samples taken from plants in domestication was positive.

\section{Incidence of YMV and YMMV}

The 12 leaf samples of both $D$. praehensilis and D. abyssinica species positive at ACPELISA test, were analyzed by RT-PCR. However, only 2 of these leaf samples were positive for YMV as indicated by the results reported in Table 6. This corresponds to an incidence rate of YMV estimated at $16.67 \%$ for the 12 leaf samples analyzed and at $1.12 \%$ for all the 179 leaf samples of the two yam species collected in the four regions of Togo. Among these 2 leaf samples positive for YMV, 1 was taken from a plant of $D$. abyssinica in domestication (i.e. an incidence 
rate of $0.93 \%$ ) and 1 sample was collected from a plant of $D$. praehensilis located near a cultivated yam plot in the District of Agou
(Plateaux region), ie an incidence rate of YMV estimated at $1.37 \%$. In contrast, for YMMV, no sample was positive.

Table.1 Number of wild yam leaf sampled collected in the four yam producing areas of Togo

\begin{tabular}{|c|c|c|c|c|c|c|c|c|}
\hline \multirow{2}{*}{ Wild yam species } & \multicolumn{6}{|c|}{ wild yam leaves collection areas and environments } & Total \\
\hline & MR & PR & CR & KR & Domestication & Forest & \\
\hline D. abyssinica & $1^{* *}$ & 29 & 71 & 6 & 3 & 104 & $\mathbf{1 0 7}$ \\
\hline D. praehensilis & 0 & 63 & 9 & 0 & 11 & 61 & $\mathbf{7 2}$ \\
\hline Total & $\mathbf{1}$ & $\mathbf{9 2}$ & $\mathbf{8 0}$ & $\mathbf{6}$ & $\mathbf{1 4}$ & $\mathbf{1 6 5}$ & $\mathbf{1 7 9}$ \\
\hline
\end{tabular}

*MR $=$ Maritime region, $\mathrm{PR}=$ Plateaux region, $\mathrm{CR}=$ Central region, $\mathrm{KR}=$ Kara region

** Yam plant in domestication at Agronomic Experimentation Station of the Higher School of Agronomy, University of Lomé

Table.2 List of primers used for the detection of YMV and YMMV and their sources

\begin{tabular}{|l|l|l|l|l|}
\hline Primers & Sequences & $\begin{array}{l}\text { Size of } \\
\text { cDNA } \\
\text { fragments }\end{array}$ & $\begin{array}{l}\text { Viruses } \\
\text { detected }\end{array}$ & Sources \\
\hline $\begin{array}{l}\text { YMV1 } \\
\text { YMV2 }\end{array}$ & $\begin{array}{l}\text { 5'-TGCGGAACTCRAAAGAAC-3 } \\
\text { 5'-TGCCATCAAATCCAAACA-3' }\end{array}$ & $196 \mathrm{pb}$ & YMV & $\begin{array}{l}\text { Bousalem et } \\
\text { al., (2000b) }\end{array}$ \\
\hline $\begin{array}{l}\text { YMV-CP-2F } \\
\text { YMV-UTR- } \\
\text { 1R }\end{array}$ & $\begin{array}{l}\text { 5'-GGCACACAT GCAAATGAA AGC-3' } \\
\text { 5'-CACCAGTAGAGTGAACAT AG-3' }\end{array}$ & $\mathbf{2 4 9}$ pb & YMMV & $\begin{array}{l}\text { Mumford \& } \\
\text { Seal (1997) }\end{array}$ \\
\hline
\end{tabular}

Table.3 List of the Districts of the wild yam leaf samples collection and the number of samples collected

\begin{tabular}{|c|c|c|c|c|c|c|c|}
\hline \multirow[t]{2}{*}{ Regions } & \multirow[t]{2}{*}{ Districts } & \multicolumn{2}{|c|}{ Wild yamspecies } & \multirow[t]{2}{*}{ Regions } & \multirow[t]{2}{*}{ Districts } & \multicolumn{2}{|c|}{ Wild yamspecies } \\
\hline & & D. abyssinica & $\begin{array}{c}D . \\
\text { praehensilis }\end{array}$ & & & D. abyssinica & $\begin{array}{c}D . \\
\text { praehensilis }\end{array}$ \\
\hline MR & Gulfe* & 1 & 0 & \multirow[t]{5}{*}{$\mathrm{CR}$} & Tchamba & 16 & 0 \\
\hline \multirow[t]{7}{*}{ PR } & Agou** & 0 & 12 & & Sotouboua & 27 & 0 \\
\hline & Kloto** & 0 & 14 & & Tchaoudjo & 17 & 0 \\
\hline & Haho & 0 & 10 & & Binah & 2 & 0 \\
\hline & Badou** & 0 & 9 & & Blitta* & 9 & 9 \\
\hline & Ogou & 0 & 9 & \multirow[t]{3}{*}{ KR } & Bassar & 3 & 0 \\
\hline & Anié & 7 & 2 & & Doufelgou & 1 & 0 \\
\hline & $\begin{array}{c}\text { Est- } \\
\text { mono**** }\end{array}$ & 22 & 7 & & Keran & 2 & 0 \\
\hline
\end{tabular}

* Collecting localities of leaves of $D$. abyssinica domesticated

** Localities of collection of leaves samples of $D$. praehensilis in domestication

*** Localities of collection of leaves samples of D. abyssinica and D. praehensilis in domestication 
Table.4 Number of yam leaf samples positive for Potyviruses by wild yam species and by District

\begin{tabular}{|c|c|c|c|c|c|c|c|}
\hline \multirow[t]{2}{*}{ Regions } & \multirow[t]{2}{*}{ Districts } & \multicolumn{2}{|c|}{ Wild yamspecies } & \multirow[t]{2}{*}{ Regions } & \multirow[t]{2}{*}{ Districts } & \multicolumn{2}{|c|}{ Wild yamspecies } \\
\hline & & D. abyssinica & D. praehensilis & & & D. abyssinica & D. praehensilis \\
\hline MR & Gulfe* & $1 / 1$ & - & \multirow[t]{5}{*}{ CR } & Tchamba & $0 / 16$ & - \\
\hline \multirow[t]{7}{*}{ PR } & Agou** & - & $2 / 12$ & & Sotouboua & $0 / 27$ & - \\
\hline & Kloto** & - & $0 / 14$ & & Tchaoudjo & $0 / 17$ & - \\
\hline & Haho & - & $0 / 10$ & & Binah & $0 / 2$ & - \\
\hline & Badou** & - & $0 / 9$ & & Blitta* & $1 / 9$ & $0 / 9$ \\
\hline & Ogou & - & $0 / 9$ & \multirow[t]{3}{*}{ KR } & Bassar & $1 / 3$ & - \\
\hline & Anié & $2 / 7$ & $0 / 2$ & & Doufelgou & $0 / 1$ & - \\
\hline & $\begin{array}{c}\text { Est- } \\
\text { mono*** }\end{array}$ & $4 / 22$ & $0 / 7$ & & Keran & $1 / 2$ & - \\
\hline
\end{tabular}

* Collecting localities of leaves of D. abyssinica domesticated

** Localities of collection of leaves samples of $D$. praehensilis in domestication

*** Localities of collection of leaves samples of D. abyssinica and D. praehensilis in domestication

Table.5 Potyvirus incidence rates by wild yam species and number of positive yam leaf samples by region

\begin{tabular}{|l|c|c|c|c|c|c|c|c|}
\hline \multirow{2}{*}{$\begin{array}{c}\text { Wild } \\
\text { yamspecies }\end{array}$} & \multicolumn{6}{|c|}{ wild yam leaves collection areas and environments } & Total & $\begin{array}{c}\text { Incidence } \\
\text { rates (\%) }\end{array}$ \\
\cline { 2 - 10 } & MR* & PR & CR & KR & Domestication & Forest & & \\
\hline D. abyssinica & $1 / 1$ & $6 / 29$ & $1 / 71$ & $2 / 6$ & $3 / 3$ & $7 / 104$ & $\mathbf{1 0 / 1 0 7}$ & $\mathbf{9 , 3 5}$ \\
\hline D. praehensilis & 0 & $2 / 63$ & $0 / 9$ & 0 & $1 / 11$ & $1 / 61$ & $\mathbf{2 / 7 2}$ & $\mathbf{2 , 7 8}$ \\
\hline Total & $\mathbf{1 / 1}$ & $\mathbf{8 / 9 2}$ & $\mathbf{1 / 8 0}$ & $\mathbf{2 / 6}$ & $\mathbf{4} / \mathbf{1 4}$ & $\mathbf{8 / 1 4 1}$ & $\mathbf{1 2 / 1 7 9}$ & $\mathbf{6 , 7 0}$ \\
\hline
\end{tabular}

*MR $=$ Maritime region, $\mathrm{PR}=$ Plateaux region, $\mathrm{CR}=$ Central region, $\mathrm{KR}=$ Kara region

Table.6 Reactions of Potyviruses positive leaf samples of $D$. praehensilis and D. abyssinica, to YMV and YMMV detection analyzes

\begin{tabular}{|c|c|c|c|c|c|c|c|}
\hline \multirow[t]{3}{*}{ Regions } & \multicolumn{4}{|c|}{ Wild yam species } & \multirow{2}{*}{\multicolumn{2}{|c|}{$\begin{array}{l}\text { Positive wild yam leaves } \\
\text { collection environments }\end{array}$}} & \multirow[t]{3}{*}{ Total } \\
\hline & \multicolumn{2}{|c|}{ D. abyssinica } & \multicolumn{2}{|c|}{ D. praehensilis } & & & \\
\hline & YMV & YMMV & YMV & YMMV & Domestication & Forest & \\
\hline MR & $1 / 1$ & $0 / 1$ & - & - & $1 / 1$ & - & $1 / 1$ \\
\hline PR & $0 / 6$ & $0 / 6$ & $1 / 2$ & $0 / 2$ & - & $1 / 1$ & $1 / 8$ \\
\hline CR & $0 / 1$ & $0 / 1$ & 0 & 0 & - & - & $0 / 1$ \\
\hline KR & $0 / 2$ & $0 / 2$ & 0 & 0 & - & - & $0 / 2$ \\
\hline Total & $1 / 10$ & 0/10 & $1 / 2$ & $0 / 2$ & & & $2 / 12$ \\
\hline
\end{tabular}

Potyviruses were detected in the two wild yam species studied, D. abyssinica and $D$. praehensilis, but virus incidence rates were highly variable depending on the yam species and the regions surveyed. In indeed, in the Maritime and Plateaux regions, with a soft and humid climate, Potyviruses were detected in both wild yam species, however, with an 
incidence rate of the virus higher in $D$. abyssinica. In the Central and Kara regions, with a hot and dry climate, only $D$. abyssinica species was infected by Potyviruses but at very low rates. No sample of $D$. praehensilis collected in the Central Region was positive for Potyviruses despite the proximity of some wild yam plants to cultivated yam plots. These variations in the incidence rates of Potyviruses according to agroecological zones were also observed in Togo on yams of the complex D. cayenensis-rotundata (Ayisah et al., 2011)and this would be due to agroecological conditions, in particular to climate, and also, to the abundance of viruses and their vectors (Thresh et al., 2003; Astier et al., 2001).

Furthermore, depending on the development environment of the wild yam plants analyzed, the incidence rates of Potyviruses were also variable. Indeed, the results showed that $100 \%$ of the leaves taken from $D$. abyssinica plants in domestication were infected against only $6.73 \%$ of the samples collected in the forest. On D. praehensilis, $9.09 \%$ of leaves from plants in domestication were positive compared to $1.64 \%$ of those taken from wild plants. This suggests that in their natural habitats, both wild yam species are less prone to Potyvirus infections than in yam fields where infection conditions appear stronger; the importance of virus sources, the abundance and activity of vectors, and the susceptibility of plants being the main factors that promote virus expansion (Astier et al., 2001).

The low contamination rate of samples of $D$. praehensilis compared to those of $D$. abyssinica, suggests a greater sensitivity of the latter species. This has been observed in the laboratory, during mechanical inoculations using isolates of YMV, where $D$. abyssinica has been shown to be very susceptible to the virus unlike $D$. praehensilis
(Ayisah, 2012; Ayisah et al., 2020). Nevertheless, it should be noted in general that the two species of yams were very weakly infected by Potyviruses.

In addition, of a total of 12 Potyviruses positive leaf samples analyzed, only 2 were infected by YMV, of which 1 sample taken from a plant of $D$. abyssinica in domestication and 1 harvested from $D$. praehensilis near a cultivated yam plot. But no sample was infected by YMMV. This suggests that, in their habitats, these wild yam species are not specifically susceptible to the two most important viruses that infect cultivated yams in West Africa (Brunt et al, 1996; Njukeng, 1998).The two YMV infections detected on D. abyssinica and on D. praehensilis, would have come from cultivated yams, in particular from yams of the complex $D$. cayenensisrotundata very sensitive to virus infections (Hughes, 1997; Porth et al., 1987). It is also possible that some of the yam plants infected by the virus are the product of interspecific hybridizations. Indeed, many cases of interspecific hybridizations between different yam species, especially between wild yams, D. abyssinica, D. praehensilis, and cultivated yam species (D. rotundata, D. cayenensis) have been reported (Scarcelli et al., 2006; Zannou et al., 2009). This suggests the need to carry out a preliminary study to identify populations of wild yams resulting from spontaneous hybridization with cultivated species (potentially sensitive to viruses) with a view to better use in variety improvement programs. On the other hand, more than $83 \%$ of the wild yams leaf samples positive at ACP-ELISA test, were infected by Potyviruses other than YMV and YMMV. Similar results were obtained on yams of the complex D. cayenensis-rotundata cultivated in Togo where, more than $43 \%$ of leaf samples analyzed were contaminated by other species of Potyviruses (Ayisah, 2012). It is therefore possible that some of the 
Potyviruses identified in the wild yams are the same as those which infect yams of the complex D. cayenensis-rotundata. This suggests the need to make an inventory of the Potyviruses which infect the two yam species $D$. abyssinica and D. praehensilis and to know their links with the viruses of cultivated yams.

In conclusion, it emerges from the present study that wild yams, D. abyssinica and $D$. praehensilis, regularly involved in the process of farmers' domestication in Togo, are infected by Potyviruses. However, the incidence of the Potyviruses is generally very low, especially for $D$. praehensilis. Furthermore, these yams were not specifically susceptible to YMV and YMMV in their habitats. This suggests that the two species of spontaneous yams actually contain sources of resistance that can be exploited in variety improvement programs. But given the possibilities of infection by YMV and of interspecific hybridizations with cultivated yams which can lead to genotypes sensitive to viruses, it would be necessary to search beforehand for potentially sensitive interspecific hybrid populations among these wild yams before any exploitation as sources of resistance. It is also important to know the nature of the Potyviruses which infect the two spontaneous yam species as well as their links with the viruses of cultivated yams.

\section{References}

Adjata, K.D. 1991. Application of EnzymeLinked Immunosorbent Assay (ELISA) to the detection of yam potyviruses (Dioscorea spp). End of agronomic studies thesis $\mathrm{n}^{\circ} 90 / 01 / \mathrm{PV}$, E.S.A.- UL. (Lome-Togo. French.

Astier, S., Albouy, J., Maury, Y., Lecoq, H. 2001. Principles of plant virology: Genome, pathogenicity, virus ecology. INRA ed. Versailles. French.
Attiri, G.I., Winter, S. and Alabi, J.O., 2003. Yam. In: Loebenstein, G. \& Thottappilly G. 2003. Virus and Virus -like Diseases of Major Crops in Developing Countries. Kluwer Academic Publishers, Dordrecht, Nethrelands.

Ayisah, K.D., Muller, E., Gumedzoe, Y.M.D. 2011. Incidence and distribution of yam mosaic virus (YMV) in yam crops of the complex Dioscorea cayenensisrotundatain Togo. Rech. Sc., Series A 13(2): 23-33. French.

Ayisah, K.D. 2012. Molecular variability of the yam mosaic virus (YMV) on the complex Dioscorea cayenensisrotundatain Togo and search for sources of resistance in local yam populations (cultivated and wild). Unique PhD thesis in Developmental Biology, Specialty: Phytopathology. Order number: 418, Faculty of Sciences of University of Lomé, Togo, B.P.: 1515 Lomé-Togo. French.

Ayisah, K.D, Mawussi, G., Tchaniley, L. and Aziadekey, M.K. 2020. Potentials of Cultivated Varieties and Wild Yam Seeds as Efficient Alternative Plant Genetic Resources for Resistant Genotypes against Yam Mosaic Virus (YMV) in Togo. Journal of Experimental Agriculture International. 42(7): 82-93

Bousalem, M., Dallot, S. and Guyader, S. $2000 \mathrm{~b}$. The use of phylogenic data to develop molecular tools for the detection and genotyping of Yam mosaic virus. Potential application in molecular epidemiology. Journal of virological Methods, 90: 25-36.

Brunt, A.A., Crabtree, K., Dalwitz, M.J., Gibbs, A. and Watson, L. 1996. Viruses of Plants. Description and Lists from the VIDE Database CAB International, Wallingford/Cambridge, UK. 
FAOSTAT, 2020. F.A.O. Agriculture database. FAO statistical yearbook. Vialedelle Terme di Caracalla 00153 Rome, Italy

Hamon, P. 1987. Structure, genetic origin of cultivated yams of the Dioscorea cayenensisrotundata complex and domestication of yams in West Africa. Doctoral thesis, ORSTOM, Paris. French.

Hughes, J. d'A, Dongo, L. and Ng, S.Y.C. 1998. Diagnosis of yam viruses. Tropical Agriculture, 75: 45-48

Hughes, J. d'A., Dongo, L.N. and Attiri, G.I. 1997. Viruses infecting cultivated yams (Dioscorea alataand D. rotundata) in Nigeria. Phytopathology (Supplement), 87: 45.

ITRA (Togolese Institute for Agronomic Research). 2009. Stratification of Togo into homogeneous zones for agronomic research In: Annual Report 2009. ITRA. Lomé, Togo. Pp. 25-28. French.

Mignouna, H. D. and Dansi, A. 2003. Yam (Dioscorea spp.) domestication by the Nago and Fon ethnic groups in Benin. Genetic Resources and Crop Evolution, 50: 519-528.

Mumford, R.A. and Seal, S.E. 1997. Rapid single-tube immunocapture RT-PCR for the detection of two yam potyviruses. Journal of Virological Methods, 69: 73-9.
Njukeng, P.N.1998. Development of Sensitive Indexing Techniques for Diagnosing Yam Mosaic Potyvirus in Yams, Dioscorea species. Ph.D. Thesis, University of Ibadan, Ibadan, 200284 Oyo State, Nigeria.

Porth, A., Lesemann, D.E. and Vetten, H.J. 1987.Characterization of Potyvirus isolat from West Africa Yams (Dioscorea spp.). Journal of phytopathology, 120: 166-183.

Scarcelli, N., Tostain, S., Mariac, C., Agbangla, C., Daïnou, O., Berthaud, J. and Pham, J.-L. 2006. Genetic nature of yams (Dioscorea sp.) domesticated by farmers in Benin (West Africa). Genetic Resources and Crop Evolution, 53: 121-130

Thresh, J. M., Fargette, D. and Jeger, M. J. 2003. Epidemiology of tropical plant virusesIn: Loebenstein, $\mathrm{G}$ and Thottappilly, G (Eds), Virus and Viruslike diseases of major crops in developing countries. Kluwer Academic Publishers, The Netherlands, UK. Pp. 55-77.

Zannou, A., Agbicodo, E., Zoundjihékpon, J., Struik, P. C., Ahanchédé, A. Kossou, D. K. and Sanni, A. 2009. Genetic variability in yam cultivars from the Guinea-Sudan zone of Benin assessed by random amplified polymorphic DNA. African Journal of Biotechnology, Vol. 8: 026-036.

\section{How to cite this article:}

Kwasi Dzola Ayisah, Gbenonchi Mawussi and Larounga Tchaniley. 2020. Incidence of Potyviruses on Two Wild Yams Species, Potential Varietal Improvement Plant Genetic Resources, Involved in Farmers' Domestication Process in Togo. Int.J.Curr.Microbiol.App.Sci. 9(10): 1230-1238. doi: https://doi.org/10.20546/ijcmas.2020.910.148 